Article

\title{
The Tragedy of the "Tragedy of the Commons": Why Coining Too Good a Phrase Can Be Dangerous
}

\author{
Robert Stephen Hawkshaw ${ }^{1{ }^{*}}$, Sarah Hawkshaw ${ }^{2}$ and U. Rashid Sumaila ${ }^{2}$ \\ 1 Faculty of Law, University of British Columbia, 1822 East Mall, Vancouver, V6T 1Z1, Canada \\ 2 Fisheries Centre, 2202 Main Mall, Vancouver, BC, V6T, Canada; \\ E-Mails: s.hawkshaw@fisheries.ubc.ca (S.H.); r.sumaila@fisheries.ubc.ca (U.R.S.) \\ * Author to whom correspondence should be addressed; E-Mail: stephen.hawkshaw@gmail.com; \\ Tel.: +1-604-822-2731; Fax: +1-604-822-8934.
}

Received: 28 August 2012; in revised form: 30 October 2012 / Accepted: 13 November 2012 / Published: 15 November 2012

\begin{abstract}
A deep reading of Hardin (1968) reveals that he had a lot more to say about the use and regulation of resources such as fisheries than he is given credit for in the literature. It appears that he is typically cited just so that authors can use the phrase "tragedy of the commons" to invoke the specter of looming catastrophe and then tie that to whatever solution they have proposed. We argue in this contribution that there is a lot more in Hardin's essay that either contradicts or greatly complicates the arguments he is cited as an authority for.
\end{abstract}

Keywords: tragedy of the commons; fisheries economics; individual transferable quotas

\section{Introduction}

Hardin's "Tragedy of the Commons" is a simple and highly effective metaphor that has stuck with us. Rational economic actors who have no limit on the amount of a resource they can extract will overexploit and destroy common pool resources:

Picture a pasture open to all. It is to be expected that each herdsman will try to keep as many cattle as possible on the commons... But this is the conclusion reached by each and every rational herdsman sharing the commons. Therein is the tragedy. Each man is locked into a system that compels him to increase his herd without limit-in a world that is 
limited. Ruin is the destination toward which all men rush, each pursuing his own best interest in a society that believes in the freedom of the commons ([1], p. 1224).

Hardin is making a simple argument. Greed or self-interest is not always good and the invisible hand is not to be trusted to make socially optimal choices in these situations. However, since its popularization, the invisible hand has "ever since interfered with positive action based on rational analysis" because it incorrectly promotes the assumption "that decisions reached individually will, in fact be the best decisions for an entire society" ([1], p. 1244). Hardin suggests two possible solutions for the problem of overexploitation of common pool resources; sell them off as private property or keep them as public property and allocate the right to use them ([1], p. 1245).

In fisheries policy literature there is a trend surrounding the use of Hardin's "tragedy of the commons", which is invoked, followed by a reference to the "race to fish" [2] and then privatization of a fishery is suggested as a solution. This leaves the readers with the thought that Individual Transferable Quotas (ITQ), or catch shares are required to address an ongoing tragedy for the commons, but in reality they are addressing a different issue - the maximization of economic rent and economic efficiency [3]. A few exceptions to this general tendency are [4,5].

The majority of the fish caught around the globe are within the 200 nautical mile Exclusive Economic Zone (EEZ) of one nation or another [6]. For the most part, articles citing the tragedy of the commons concern the management of the fisheries of developed countries. Deploying the tragedy of the commons for these fisheries is inappropriate because Hardin's article was specifically aimed at open access resources (pastures open to all). The coastal fisheries of developed countries (provided they do not stray into the high seas) are de jure not part of the type of commons imagined by Hardin. This is perfectly clear from a legal perspective. Although the main thrust of the resource related articles of the United Nations Convention on the Law of the Sea (UNCLOS) concern the exploitation of oil and gas and subsurface minerals, Articles 56 and 61 also cover the ownership of fish. They read:

Article 56

Rights, jurisdiction and duties of the coastal State in the exclusive economic zone

1. In the exclusive economic zone, the coastal State has:

(a) sovereign rights for the purpose of exploring and exploiting, conserving and managing the natural resources, whether living or non-living, of the waters superjacent to the seabed and of the seabed and its subsoil, and with regard to other activities for the economic exploitation and exploration of the zone, such as the production of energy from the water, currents and winds.

\section{Article 61}

Conservation of the living resources

1. The coastal State shall determine the allowable catch of the living resources in its exclusive economic zone.

2. The coastal State, taking into account the best scientific evidence available to it, shall ensure through proper conservation and management 
measures that the maintenance of the living resources in the exclusive economic zone is not endangered by over-exploitation. As appropriate, the coastal State and competent international organizations, whether subregional, regional or global, shall cooperate to this end.

These two articles make it clear that the signatory coastal nations of UNCLOS own the fish in their EEZ and have a mandatory responsibility to determine and enforce a total allowable catch. Every major fishing nation, save the United States of America, has signed the treaty. Despite not signing the treaty the United States still recognizes these sections as codifications of existing customary international law ([7], p. 29). The same basic principles can be seen in the domestic legislation of developed fishing nations.

Simply put, the capital-intensive fisheries in developed countries are currently not a commons in the sense that Hardin used. The fish have an owner (the state) and the owner has agreed to restrictions on the number of fish caught. A simple thought experiment in the same style as Hardin's shows this easily. Instead of a herdsmen moving cattle onto pasture, we shall imagine a strange fishing boat setting out nets or traps in a commonly fished area. What would the consequences be? Would the other fishers sit idly by? Would the state? No, they would not. Depending on how feisty the fishers or state actors were feeling, we would expect a range of consequences to new fishers moving into a fishery or violating regulations. There could be a fine. Your nets or traps could be destroyed, or your boat set on fire [8]. The fishing authorities could shoot at you, arrest you and confiscate your boat [9]. There are de jure and de facto obligations and rights (or privileges) of access to these fisheries and being caught violating them will lead to consequences, in most cases.

If this is the case, why is Hardin's work so widely cited in literature? He is cited widely because he is the frequent victim of drive-by-citation. The tragedy of the commons is invoked because it sounds good, not for what Hardin was actually advocating. For example:

It is by now widely recognized (Scott, 1955; Neher et al., 1989; Shotton, 2000) that the basic problem of economic inefficiency in fisheries - often referred to as the common property problem (Gordon, 1954) and, more dramatically, the tragedy of the commons (Hardin, 1968)—stems fundamentally from inadequate or lacking property rights in the underlying natural resources, namely, the fish stocks and their ocean habitat. Due to this lack of property rights, trades in the natural resources cannot occur. As a result markets cannot form and, consequently, there are no market forces to guide behavior to the common good in the way made famous by Adam Smith (1776) and many authors after him. ([10], p. 244).

This theme of there being only two options, privatization leading to conservation and wealth or the waste of the resource under the "tragedy of the commons" is common:

How natural resources contribute to economic development largely depends upon whether they become assets, nurtured by users, or whether rents are dissipated through a "tragedy of the commons." Maximizing the rental stream requires a system of property rights that avoids a competitive race for rents and instills incentives for conservation of the resource and efficient production from it. The alternative of open access leads to excessive 
short-term output, underinvestment, and limited trade, reducing the wealth and welfare of those whose livelihoods often depend upon the natural resource. ([11], p. 79).

These quotes are typical of the school of thought in the literature that advocates for the implementation of ITQs and certainly gives the impression that Hardin was advocating for widespread privatization of fisheries and reliance on the "invisible hand" to solve difficult social and allocation issues:

The structure of property rights has long been considered one of the most important factors affecting economic development and efficiency. For common-pool resources, where yields are rivalrous and use is only partially excludable, the absence of controls over access leads to the "tragedy of the commons." Fisheries provide the classic case of open access, where market failures arise, in part, because agents are unable to contract to exclude others and prevent rent dissipation. One solution to the problems of open access is the "privatization of the commons" or the creation of individual private property rights for common-pool resources. ([12], p. 680)

We do not believe this to be a correct reading of Hardin's essay. Once some form of total allowable catch is set we are outside the main thrust of Hardin's tragedy. His driving concern was overexploitation, not allocation. However, there are aspects of Hardin's essay that could be usefully invoked in the fisheries context and indeed in arguments for ITQs.

\section{What Hardin's Article Was Actually About}

If Hardin's article is not a rallying cry for the privatization of public resources, what does it actually stand for and what was Hardin advocating for? Hardin's first point is this: some problems do not have technical solutions. Science can mitigate or delay a problem for a time but eventually a hard choice has to be made. Some people do not like to acknowledge that some problems have no technical solutions because doing so may result in the reduction of their status as the experts.

\section{Hardin's Second Major Point}

In the case where there are no certain technical solutions to a problem, hard choices are required and some system of evaluating those choices must be developed. Incommensurables must be compared. For Hardin, developing criteria for comparing different policy goals and outcomes is the real challenge:

"We want the maximum good per person; but what is good? To one person it is wilderness, to another it is ski lodges for thousands. To one it is estuaries to nourish ducks for hunters to shoot; to another it is factory land. Comparing one good with another is, we usually say, impossible because goods are incommensurable. Incommensurables cannot be compared. Theoretically this may be true; but in real life incommensurables are commensurable. Only a criterion of judgment and a system of weighting are needed. In nature the criterion is survival. Is it better for a species to be small and hideable, or large and powerful? Natural selection commensurates the incommensurables. The compromise achieved depends on a natural weighting of the values of the variables. 
The problem for years ahead is to work out an acceptable theory of weighting. Synergistic effects, nonlinear variation, and difficulties in discounting the future make the intellectual problem difficult, but not (in principle) insoluble.” ([1], p. 1244)

We think that much of the literature has missed this key point. Proponents of ITQs tend to downplay or sideline distributional and social equity issues as a problem for someone else to solve [12-14]. The focus is on "economic efficiency" and the aim is always the maximization of efficiency with the goal of allowing private industry to capture supernormal profits.

\section{The Tragedy of the Commons}

Hardin's article uses the metaphor of "tragedy of the commons". However, he introduces this metaphor for the purposes of debunking the idea that laissez-fair markets produce socially optimal outcomes without state regulation:

We can make little progress...until we exorcize the spirit of Adam Smith...In economic affairs, The Wealth of Nations (1776) popularized the "invisible hand," the idea that an individual who "intends only his own gain", is as it were, "led by an invisible hand to promote...the public interest”. ([1], p. 1244)

Hardin's position is that since its invention, Adam Smith's invisible hand has “ever since interfered with positive action based on rational analysis, namely, the tendency to assume that decisions reached individually will, in fact, be the best decisions for an entire society." ([1], p. 1244) The "tragedy of the commons" is introduced to rebut the invisible hand ([1], p. 1244):

The rebuttal to the invisible hand...is to be found in a scenario first sketched in a little-known pamphlet...We may well call it "the tragedy of the commons,"... ([1], p. 1244)

This is probably the most over emphasized point in the entire essay. Hardin has a lot of interesting and important things to say that get glossed over in the rush to either apply this model as an excuse for enclosures or decry it for its historical (or legal) inaccuracies. Adam Smith's theory of the invisible hand suffers from similar readings. In Smith's eyes the market did not always lead to favourable outcomes and licensing schemes developed to restrict access to industry were harmful to the public [15].

\subsection{Hardin's Solution to the Tragedy}

The way Hardin is cited in fisheries policy literature seems to suggest that his solution to the tragedy was the complete privatization of all public resources. In actual fact, his article put forward a range of possible solutions, one of which happens to have been the sale of public resources to private interest ([1], p. 1245). However, when it comes to resources like fisheries he seems to favour taxation or state regulation over private property. In Hardin's view, private property rights are sometimes not enough to avert the tragedy of the commons. When property cannot be readily contained or demarcated, regulations and taxation in conjunction with property rights might be more appropriate:

The rational man finds that his share of the costs of the wastes he discharges into the commons is less than the cost of purifying his wastes before releasing them. Since this is true for everyone, we are locked into a system of "fouling our own nest," so long as we 
behave only as independent, rational free-enterprisers. The tragedy of the commons as a food basket is averted by private property, or something formally like it. But the air and the waters surrounding us cannot readily be fenced, and so the tragedy of the commons as a cesspool must be prevented by different means, by coercive laws or taxing devices...([1], p. 1245)

We believe that Hardin would view fisheries as one of these situations where the tragedy of the commons is best solved by the institution of coercive laws or taxes rather than, or in addition to, private property. In fact, much of the literature on ITQs recognizes that ITQs will require increased enforcement and monitoring [16,17]. Without this monitoring and enforcement the temptation to quota bust, high grade and discard by-catch will actually result in over fishing, rent dissipation or even exploitation to the point of extinction [16].

\subsection{Hardin Did Not Advocate For Less Regulation}

After laying out the "tragedy of the commons" Hardin makes the case for instituting flexible and adaptable laws. Dealing with the tragedy of the commons will require the creation and empowerment of regulatory oversight bodies - bodies that have the power to enact and enforce regulation in the best interests of society and over the objections of specific interest groups. These regulatory bodies will need to be set up in such a way as to avoid regulatory capture and caprice:

Bureau administrators, trying to evaluate the morality of acts in the total system, are singularily liable to corruption, producing a government by men, not laws...The great challenge facing us now is to invent the corrective feedbacks that are needed to keep custodians honest. We must find ways to legitimate the needed authority of both the custodians and the corrective feedbacks. ([1], p. 1246)

Hardin is most frequently cited for the 'private property' aspect of his essay and not this crucial point. Hardin is trying to lay out both the moral basis for environmental regulation and methods for preventing its misuse. Given his reasoning it is contradicting to see proponents of ITQs cite Hardin and then argue for self-regulation. $[13,17]$

\subsection{Regulation versus Persuasion}

Hardin also takes a strong stance against relying on morals and values to temper or shape the effect of private markets on the environment. In his view, appeals to conscience and propaganda are in the long run ineffective - it is foolish to set up a system that rewards certain behavior (over-fishing, quota busting, discarding, and high-grading) and expect moral suasion to substitute for effective enforcement:

Some people have proposed massive propaganda campaigns to instill responsibility into the nation's (or world's) breeders. But what is the meaning of the word responsibility in this context? Is it not merely a synonym for the word conscience? When we use the word responsibility in the absence of substantial sanctions are we not trying to browbeat a free man in a commons into acting against his own interest? Responsibility is a verbal counterfeit for a substantial quid pro quo. It is an attempt to get something for nothing. (...) 
"Responsibility," says this philosopher "is the product of definite social arrangements."

Notice that Frankel calls for social arrangements—not propaganda. ([1], p. 1247)

Instead of propaganda without financial compensation, the solution for Hardin is coercion. The whole point of this exercise is to produce responsibility for actions. You cannot create responsibility without coercion and sanctions. Sometimes prohibitions are called for and sometimes coercion:

We need not actually forbid a citizen to park as long as he wants to; we need merely make it increasingly expensive for him to do so. Not prohibition, but carefully biased options are what we offer him. A Madison Avenue man might call this persuasion; I prefer the greater candor of the word coercion. ([1], p. 1247)

We can think of two ways that this aversion to propaganda applies to the fisheries context. The first is the environmental movement's attempts to shape consumer preferences and pressuring fish producers to adopt environmentally friendly fishing techniques. A case can probably be made that these efforts have been ineffective except where money has also been involved-whales are still caught for food despite massive protests, etc. The second area where this might apply is community based fisheries management, but again we think in the community setting moral arguments are always implicitly backed by sanctions such as expulsion from the community, loss of standing, or violence.

Hardin also makes the point that broad stakeholder participation is required for a solution to be effective and legitimate:

The only kind of coercion I recommend is mutual coercion, mutually agreed upon by the majority of the people affected. ([1], p. 1247)

One of the stakeholders frequently left out is the general public. To be fair this is true of both proponents of ITQ fisheries and community-managed fisheries, both of which favour current resource users over the general public. This is a dubious position to take in many real world fisheries where the existing users have typically been the recipients of decades of massive subsidies and state granted monopolies [18]. It also takes for granted the existence of some redistribution systems (income taxes are usually put forward as solving the problem), while ignoring the fact that most fisheries benefit from special tax treatment and tax exemptions (subsidies) that prevent this redistribution. If fisheries were truly a common pool resource then everyone who is excluded from participating in the fishery should have a say and in keeping with Hardin's dislike of moral suasion should get some sort of payment or quid pro quo for their exclusion. This also implies a vote or some sort of democratic decision making process instead of a top down instituted regulatory or property regime.

\subsection{Point Fourteen}

Hardin also identified what he viewed as the major challenges facing efforts to reform the status quo:

Whenever a reform measure is proposed it is often defeated when its opponents triumphantly discover a flaw in it. As Kingsley Davis has pointed out, worshippers of the status quo sometimes imply that no reform is possible without unanimous agreement, an implication contrary to historical fact. (...) Reform rejected due to: (i) that the status quo is perfect; or (ii) that the choice we face is between reform and no action; if the proposed 
reform is imperfect, we presumably should take no action at all, while we wait for a perfect proposal.(...) Once we are aware that the status quo is action, we can then compare its discoverable advantages and disadvantages with the predicted advantages and disadvantages of the proposed reform, discounting as best we can for our lack of experience. ([1], p. 1247).

We think this bias towards maintaining the status quo is present in fisheries policy literature and (more importantly) fisheries management decisions. For example this quote from a piece advocating the introduction of ITQs and the grandfathering of existing users instead of an auction [10] makes the following argument:

Consequently, even in particular empirical cases; there can be no a priori reason to sacrifice economic efficiency, i.e., reduces the total quantity of goods available, for a more fair distribution of the remaining goods. This is not because distribution doesn't matter. The reason is that distributional considerations can, at least in principle and often in practice, be taken care of without reducing efficiency in production. Thus, it appears that those who want to sacrifice economic efficiency should be required to prove (i) that the gain in fairness outweighs the loss in production and (ii) no other ways to a fairer distribution exist. (emphasis added) ([12], p. 5).

Arnason [10] is attempting to take the status quo (existing license holders) as the baseline and any change to that baseline as flawed and having to prove itself.

Finally, Hardin also has an interesting point to make about enclosures:

Every new enclosure of the commons involves the infringement of somebody's personal liberty. Infringements made in the distant past are accepted because no contemporary complains of a loss. It is newly proposed infringements that we vigorously oppose; cries of "rights" and "freedom" fills the air. But does "freedom" mean? When men mutually agreed to pass laws against robbing, mankind became freer, not less so...I believe it was Hegel who said, "Freedom is the recognition of necessity." ([1], p. 1248)

We think this point is relevant because it directly contradicts statements made by proponents advocating ITQs regarding auctions or taxes to extract resource rent as not respecting earned but not formally recognized moral property right ([19], p. 175).

\section{Conclusions}

We believe that Hardin had a lot more to say about the use and regulation of resources like fisheries than he is given credit for. He is typically just name dropped into articles so that authors can use the phrase "tragedy of the commons" to invoke the specter of looming catastrophe and then tie that to whatever solution they have proposed. We think there is a lot in the essay that either contradicts or greatly complicates the arguments he is cited as an authority for. Actually reading the article reveals that private property and privatization was not the solution he was necessarily pushing. Hardin ends on a quote from Marx about Hegel. We will end on one as well. 
Hegel remarks somewhere that all great world-historic facts and personages appear, so to speak, twice. He forgot to add: the first time as tragedy, the second time as farce." [20].

We think the tragedy of the commons risks turning into the farce of the commons while everyone goes around citing Hardin but missing his point.

\section{Conflict of Interest}

The authors declare no conflict of interest.

\section{Acknowledgements}

This article emerged out of class discussions in Sumaila's graduate course in Fisheries Economics at the UBC Fisheries Centre, of which the Hawkshaws were members. We wish to thank the Class of 2012 for their lively discussion of this central topic during the course.

\section{References}

1. Hardin, G. Tragedy of commons. Science 1968, 162, 1243-1248.

2. Symes, D.; Crean, K. Privatization of the commons: The introduction of individual transferable quotas in developed fisheries. Geoforum 1995, 26, 175-185.

3. Bromley, D. Abdicating responsibility: The deceits of fisheries policy. Fisheries 2009, 34, 280-302.

4. Sumaila, U.R. A cautionary note on individual transferable quotas. Ecol. Soc. 2010, 15, 36.

5. Clark, C.W.; Munro, G.R.; Sumaila, U.R. Limits to the privatization of fishery resources: Reply. Land Econ. 2010, 86, 614-618.

6. United Nations Food and Agriculture Organization. The state of world fisheries and aquaculture. Rome, Italy, 1998. Available online: http://www.fao.org/docrep/w9900e/w9900e03.htm\#P4 (accessed on 11 June 2012).

7. Malone, J.L. The United States and the law of the sea after UNCLOS-iii. Law Contemp. Probl. 1983, 46, 29-36.

8. Police watch in horror as shippagan burns. $C B C$ News, 5 May 2003. Available online: http://www.cbc.ca/news/canada/new-brunswick/story/2003/05/05/nb_crabprotest20030504.html (accessed on 15 March 2012).

9. Foster, P. Diplomatic tensions after Japanese arrest Chinese fisherman. The Telegraph, 10 September 2010. Available online: http://www.telegraph.co.uk/news/worldnews/asia/japan/ 7989126/Diplomatic-tensions-after-Japanese-arrest-Chinese-fisherman.html (accessed on 15 March 2012).

10. Arnason, R. Property rights in fisheries: Iceland's experience with ITQs. Rev. Fish Biol. Fisher 2005, 15, 243-264.

11. Anderson, T.L.; Libecap, G.D. The Allocation and Dissipation of Resource Rents: Implications for Fishery Reform. In The Political Economy of Natural Resource Use: Lessons for Fisheries Reform; Leal, D.R., Ed.; World Bank: Washington, DC, USA, 2010. 
12. Grafton, R.Q.; Squires, D.; Fox, K. Common resources, private rights and economic efficiency. J. Law Econ. 2000, 43, 679-713.

13. Arnason, R. Assigning ITQs: An Economic Analysis; Prepared for Claro y Cia law firm; Ragnar Arnason: Santiago, Chile, June 2010.

14. Scott, A. New Directions in Fishery Management. In The Political Economy of Natural Resource Use: Lessons for Fisheries Reform; Leal, D.R., Ed.; World Bank: Washington, DC, USA, 2010.

15. Smith, A. An Inquiry into the Nature and Causes of the Wealth of Nations; Cannan, E., Ed.; Methuen \& Co., Ltd.: London, UK, 1904. Available online: http://www.econlib.org/library/ Smith/smWN4.html\#I.10.87 (accessed on 29 May 2012).

16. Parslow, J. Individual transferable quotas and the "tragedy of the commons". Can. J. Fish. Aquat. Sci. 2010, 67, 1889-1896.

17. Hilborn, R.W.; Orensanz, J.; Parma, A. Institutions, incentives and the future. Phil. Trans. Roy. Soc. Lond. B Biol. Sci. 2005, 360, 47-57.

18. Sumaila, U.R.; Khan, A.; Andrew, J.; Dyck, A.; Watson, R.; Munro, G.; Tyedmers, P.; Pauly, D. A bottom up re-estimation of global fisheries subsidies. J. Bioecon. 2010, 12, 201-225.

19. Anderson, T.; Arnason, R.; Libecap, G.D. Efficiency advantages of grandfathering in rights-based fisheries management. Annu. Rev. Res. Econ. 2011, 3, 159-179.

20. Marx, K. 18th Brumaire of Louis Bonaparte; Marx/Engels Internet Archive: Pacifica, USA, 1999. Available online: http://www.marxists.org/archive/marx/works/1852/18th-brumaire/ ch01.htm (accessed on 28 May 2012).

(C) 2012 by the authors; licensee MDPI, Basel, Switzerland. This article is an open access article distributed under the terms and conditions of the Creative Commons Attribution license (http://creativecommons.org/licenses/by/3.0/). 